Article

\title{
Study on the Remediation of Cd Pollution by the Biomineralization of Urease-Producing Bacteria
}

\author{
Xingqing Zhao *, Min Wang, Hui Wang, Ding Tang, Jian Huang and Yu Sun \\ School of Environmental and Safety Engineering, Changzhou University, Changzhou 213164, China; \\ mwangcz@163.com (M.W.); wh1016654221@163.com (H.W.); 18551352522@163.com (D.T.); \\ huangjian08170@163.com (J.H.); sunyu666wa@163.com (Y.S.) \\ * Correspondence: zhaoxq@cczu.edu.cn; Tel.: +86-519-86-330-086
}

Received: 27 December 2018; Accepted: 15 January 2019; Published: 18 January 2019

\begin{abstract}
Cadmium (Cd) is a highly toxic metal that can affect human health and environmental safety. The purpose of this study was to research the removal of $\mathrm{Cd}$ from an environmental perspective. In this article, four highly urease-active strains (CZW-2, CZW-5, CZW-9 and CZW-12) were isolated from an abandoned mine and their phylogenetic trees were analyzed. The maximum enzyme activities, the mineralized precipitate and the removal rates of these strains were compared. The results showed that CZW-2 had the highest urease activity at $51.6 \mathrm{U} / \mathrm{mL}$, and the removal rates of CZW-2, CZW-5, CZW-9 and CZW-12 after $120 \mathrm{~h}$ were $80.10 \%, 72.64 \%, 76.70 \%$ and $73.40 \%$, with an initial concentration of $\mathrm{Cd}$ of $2 \mathrm{mM}$ in the $\mathrm{Cd}$ precipitation experiments. XRD (X-ray diffractometer), EDS (Energy dispersive spectrometer) and FTIR (Fourier transform infrared spectroscopy) analysis indicated that the mineralized precipitate was $\mathrm{CdCO}_{3}$. SEM (Scanning electron microscopy) analysis revealed that the diameter of the oval-shaped mineralized product ranked from 0.5 to $2 \mu \mathrm{m}$. These strains were used to remedy Cd-contaminated soil, and five different fractions of $\mathrm{Cd}$ were measured. Compared with the control, the results of spraying pre-cultured strains containing $2 \%$ urea to remove $\mathrm{Cd}$ from contaminated soils showed that the exchangeable fraction of $\mathrm{Cd}$ decreased by $53.30 \%, 27.78 \%, 42.54 \%$ and $53.80 \%$, respectively, whereas the carbonate-bound fraction increased by $55.42 \%, 20.27 \%, 39.67 \%$ and $34.36 \%$, respectively, after one month. These data show that these strains can effectively reduce the bioavailability and mobility of $\mathrm{Cd}$ in contaminated soils. The results indicate that biomineralization based on the decomposition of substrate urea can be applied to remedy heavy contaminated soil and water.
\end{abstract}

Keywords: biomineralization; urease; heavy metal; sequential extraction; bioremediation

\section{Introduction}

Contamination of natural habitats by heavy metals through industrial and agricultural activities has resulted in serious excess of $\mathrm{Cd}$ content in the environment in China [1]. Cd is considered as a strong carcinogenic element and can cause damage to human health through the food chain [2]. Because of this, the hazards of $\mathrm{Cd}$ are related to its different oxidation states, mobility and bioavailability [3,4]. Therefore, remediation of Cd-contaminated water and soil is highly desired.

Considering the economic benefit and environmental protection, traditional repair methods are costly and only suitable for small areas, as they can greatly disturb the environment and are likely to cause secondary pollution [5]. Phytoremediation is an effective method to remove Cd contamination, but the plant's growth conditions depend on many elements, such as moisture, salinity, temperature and climate [6]. However, the use of the principle of biomineralization to remediate heavy metals from contaminated environments is an in situ bioremediation technology that is suitable for various geographical locations and environmental conditions and has good application prospects $[7,8]$. It is an 
emerging direction of repair and has attracted attention due to its characteristics [9]. Therefore, more researchers are increasingly interested in using microorganisms to remedy heavy metal contamination. Zhao et al. [10] reported that microbe GZ-22 has the ability to produce urease and can effectively remove $\mathrm{Cd}$ under the condition of adding substrates.

Urease (urea amide hydrolase, EC3.5.1.5) commonly exists in many microorganisms [11], and urease-producing bacteria have the ability to promote the formation of carbonate minerals and are diverse and widely distributed. The basic principle of the biochemical pathway is that bacteria produce urease to hydrolyze urea into $\mathrm{NH}^{4+}$ and $\mathrm{CO}_{3}{ }^{2-}$, and $\mathrm{NH}^{4+}$ releases $\mathrm{NH}_{3}$, which increases the average $\mathrm{pH}$ until the $\mathrm{NH}^{4+} / \mathrm{NH}_{3}$ and $\mathrm{HCO}_{3}{ }^{-} / \mathrm{CO}_{3}{ }^{2-}$ ratios achieve equilibrium [12]. Under alkaline conditions, the metal ions combine with $\mathrm{CO}_{3}{ }^{2-}$ to form a precipitation that could convert the soluble heavy metals into insoluble carbonate mineral crystals. Microorganisms immobilize heavy metals in mineral crystal lattices or convert heavy metals into insoluble minerals through metabolism to mineralize heavy metal ions, thereby reducing their mobility and bioavailability. In short, urease-producing bacteria can promote mineral precipitation, which can play a role in removing and passivating metals in soil and waste $[13,14]$. Therefore, screening and preserving the native urease-producing mineralization strains maintains the original ecological environment of in situ remediation of soil and may result in the more uniform distribution of bacteria, making it more suitable for practical engineering applications.

At present, there are many studies focusing on the hydrolysis of urea by urease-producing bacteria to produce carbonate precipitates. The previous studies revealed that researchers observed the differentiation of the physiological and biochemical characteristics of urease-producing bacteria from different regions $[8,15,16]$, and explained that urease-producing bacteria had a significant effect on removing heavy metals [11]. Recently, many urease-producing microorganisms have removed heavy metals under certain conditions, including bacterial species of Bacillus, Sporosarcina, Enterobacter, and Pseudomonas [17-20]. Annu et al. [20] reported that Saccharomyces cerevisiae has the capability to uptake $65-82 \%$ of $\mathrm{Cd}$ within 30 days when the $\mathrm{pH}$ of the soil was maintained at 5.5. Kang et al. [21] reported that $\mathrm{KJ}-46$ has high removal rates $(68.1 \%)$ of $\mathrm{Pb}$ under the initial concentration of $7.2 \mathrm{mg} / \mathrm{L}$ with excellent adaptation abilities and promising remediation efficiency. However, most studies explored the removal efficiency of heavy metals by a single microorganism [6,22], and showed that high urease activity is beneficial to increase the removal rate of heavy metals. Despite these studies, we still know little about the crystallinity, size, bioavailability and stability of $\mathrm{Cd}$ mineralization precipitates.

In the present study, the aim was to evaluate the removal rates of $\mathrm{Cd}^{2+}$, the efficiency of microorganism reduced bioavailability of heavy metals, and the differences in the carbonate crystal structure. Meanwhile, microbial reduction of heavy metal mobility and bioavailability was explored from two aspects, such as immobilization of toxic metals in vitro and for soil remediation. In addition, the relationship between the urease-producing ability of the strain and the immobilization of toxic metals, crystallinity and stability of precipitates is discussed. In order to get the effect of biomineralization, the precipitates were characterized by XRD (X-ray diffraction), FTIR (Fourier transform infrared spectroscopy), SEM-EDS (Scanning electron microscopy and energy dispersive X-ray spectroscopy), and five different fractions of $\mathrm{Cd}$ were measured by the Tessier sequential extraction procedure. This study provides experimental results and a theoretical basis for further application of microorganisms to mitigate heavy metal pollution in contaminated soils and wastewater.

\section{Materials and Methods}

\subsection{Screening Strains}

Five heavy metal contaminated soil samples were randomly collected from the Shizishan mining area, Tongling, Anhui Province, China. The characteristics and metal concentrations of the soil samples were as follows: $\mathrm{pH}$ 5.60; $46.70 \mathrm{mg} / \mathrm{kg} \mathrm{Pb;} 180.10 \mathrm{mg} / \mathrm{kg} \mathrm{Zn;} 450.20 \mathrm{mg} / \mathrm{kg} \mathrm{Cu}$; and $5.27 \mathrm{mg} / \mathrm{kg} \mathrm{Cd}$. Urease-producing strains were isolated by serially diluting $1 \mathrm{~g}$ of soil with sterile water, and samples were shaken at $170 \mathrm{rpm}$ for $6 \mathrm{~h}$. Then, the dilute soil suspensions were transferred onto a urea agar 
base (5.0 g/L beef extract, $10.0 \mathrm{~g} / \mathrm{L}$ peptone, $5.0 \mathrm{~g} / \mathrm{L} \mathrm{NaCl}, 60.0 \mathrm{~g} / \mathrm{L}$ urea, $30 \mathrm{~mL} / \mathrm{L}$ phenolphthalein), and cultured in an incubator at $30{ }^{\circ} \mathrm{C}$ for $48 \mathrm{~h}$. Finally, the colonies that changed the color of the medium from yellow to pink were selected and further purified. The lowest concentration of the metal that totally inhibits bacterial growth was considered the minimum inhibitory concentration (MIC) [23]. The isolated urease-producing bacteria were rescreened by the streak plate method on Cd containing nutrient agar plates, and the Cd concentrations were continuously increased (25-400 $\mathrm{mg} / \mathrm{L}$ ). Plates were incubated and observed for bacterial growth at $30^{\circ} \mathrm{C}$ for $48 \mathrm{~h}$.

\subsection{Identification Based on Molecular Characterization}

Genomic DNA was extracted from the logarithmic phase of bacterial cells by alkaline lysis method. The primers were designed and synthesized according to the most conserved sequence in bacterial 16S rDNA; forward primer 27F: 5'-AGAGTTTGATCCTGGCTCAG-3', reverse primer 1492R: 5'-TACCTTGTTACGACTT-3' (synthesized by Sangon Biotech Co., Ltd., Shanghai, China). The PCR amplification was performed using a thermocycler as described by Arias and Achal [14,24]. $16 \mathrm{~S}$ rDNA amplification products were sent to Sangon Biotech (Shanghai) Co., Ltd. for sequencing. Finally, the resulting sequences were submitted to GenBank for registration, and BLAST (Basic Local Alignment Search Tool) analysis was performed in the GenBank database [6]. Using ClustalX 1.8 (NCBI, Bethesda, MD, USA) for comparison and the neighbor-joining analysis of the phylogenetic tree generation system by the MEGA 5.0 software (http:/ / www.megasoftware.net) with the Kimura 2-parameter model, the phylogenetic tree was tested by the bootstrap method (1000 replicates) [25]. The 16S rDNA gene sequences of the strains were obtained and uploaded to GenBank with the following accession numbers: MG866078 (strain CZW-2), MG866079 (strain CZW-5), MG866080 (strain CZW-9) and MG866081 (strain CZW-12).

\subsection{Enzyme Activities}

During the experiment, the optical density of cultured bacteria was measured at $600 \mathrm{~nm}$ and used as an indicator of biomass density. In the absence of calcium ions, the urease activity was confirmed at regular time intervals by the electrical conductivity variation. The change of conductivity was measured with a conductivity meter according to the studies of Whiffin and Whiffin et al. [26,27]. Within the measured range of activities, our measurements of conductivity change correlated with a hydrolysis activity of $11.1 \mathrm{mM}$ urea per minute. The bacterial urease activity was equal to the change in the conductivity of the bacteria urea mixture $(\mathrm{ms} / \mathrm{cm} / \mathrm{min})$ during the measured time, multiplied by the dilution multiple, and multiplied by 11.1.

\subsection{Cd Precipitation Experiments}

The composition of LB (Luria-Bertani) liquid medium was $5.0 \mathrm{~g} / \mathrm{L}$ beef extract, $10.0 \mathrm{~g} / \mathrm{L}$ peptone, $5.0 \mathrm{~g} / \mathrm{L} \mathrm{NaCl}, \mathrm{pH} 7.0$. Taking $79 \mathrm{~mL}$ LB liquid medium into each beaker flask, all of the media were autoclaved at $121{ }^{\circ} \mathrm{C}$ for $20 \mathrm{~min}, 1 \mathrm{~mL}$ of the logarithmic phase bacteria was added in the liquid medium, the initial optical densities $\left(\mathrm{OD}_{600}\right)$ were all kept at 0.03 , and $10 \mathrm{~mL}$ of $20 \mathrm{mM} \mathrm{CdCl}_{2} \cdot 2.5 \mathrm{H}_{2} \mathrm{O}$ solution and $20.0 \mathrm{~g} / \mathrm{L}$ of urea solution filtered through $0.22 \mu \mathrm{m}$ filter were added, respectively. Then, the samples were incubated $(170 \mathrm{rpm})$ at $37^{\circ} \mathrm{C}$ for $120 \mathrm{~h}$. Samples were taken at regular time intervals and the $\mathrm{pH}$ was measured. The concentrations of $\mathrm{Cd}^{2+}$ in the samples were measured using an atomic absorption spectrometer (novAA300, Analytik Jena AG, Jena, Germany).

\subsection{SEM and EDS Analyses of the Precipitates}

The precipitate collected by centrifugation ( $8000 \mathrm{rpm}, 5 \mathrm{~min}$ ) was first fixed with $2.5 \%$ glutaraldehyde fixation solution for $1.5 \mathrm{~h}$. Then, the precipitate collected after centrifugation was formed by the addition of ethanol by $30 \%, 50 \%, 70 \%, 90 \%$ and $100 \%$ of the gradient to dehydrate for 15-20 min [28], and the resulting precipitate was dried for $6 \mathrm{~h}$ in a lyophilizer (FD-1A-50, Beijing Boyikang Laboratory Instrument Co., Ltd., Beijing, China). An SEM (JSM-6360 LA, Japan Electron Optics Laboratory Co., 
Ltd, Tokyo, Japan) was used to observe the structural morphology of the mineral precipitate at a stable voltage of $15 \mathrm{kV}$ and EDS (JSM-6360 LA, Japan Electron Optics Laboratory Co., Ltd, Tokyo, Japan) performed a detailed elemental analysis of the mineral precipitation components.

\subsection{XRD and FTIR Analyses}

The mineral composition of the precipitate was tested by an X-ray diffractometer (XRD, D-MAX2500, Japan Corporation Co., Ltd., Tokyo, Japan). The samples were fully dried and then ground to a size of 300 mesh $(48 \mu \mathrm{m})$ before they were measured on the instrument. The test conditions included a voltage of $40 \mathrm{kV}$, a tube current of $100 \mathrm{~mA}, \mathrm{CuK} \alpha=1.54056 \AA$, and a scan angle $(2 \theta)$ ranging from $5^{\circ}$ to $80^{\circ}$ in steps of $0.02^{\circ}$. FTIR was used to analyze the specific functional groups in the precipitated samples (Nicolet Avatar 370 (iS10), Thermo Nicolet Corporation, Madison, WI, USA). The infrared spectrum of the precipitate was determined by the KBr pellet pressing method, in which a 1-mg treated sample was finely mixed with $150 \mathrm{mg}$ of dried $\mathrm{KBr}$, and pressed at $10 \mathrm{t} \cdot \mathrm{cm}^{-2}$ for $2 \mathrm{~min}$. The FTIR spectrometer had a scanning wavenumber range from 500 to $4000 \mathrm{~cm}^{-1}$ and a scanning accuracy was $4 \mathrm{~cm}^{-1}$.

\subsection{Cd-Contaminated Soil Remediation}

Soils were taken from clean farmland at the National Rice Field Demonstration Base in Danyang City, China. The soil samples were exposed to heavy metal $\mathrm{Cd}$, with an initial concentration of $5.10 \mathrm{mg} / \mathrm{kg}$. Cd-contaminated soils were autoclaved at $121^{\circ} \mathrm{C}$ and were taken in a square container $(20 \mathrm{~cm} \times 10 \mathrm{~cm} \times 10 \mathrm{~cm})$. The isolated bacteria were cultured in LB liquid media about $24 \mathrm{~h}$ before irrigating the Cd-contaminated soil. Soil was sprayed with the bacteria solution $(100 \mathrm{~mL})$ containing $2 \%$ urea evenly at an interval of $24 \mathrm{~h}$ for 2 weeks and was then left for 1 month at $30^{\circ} \mathrm{C}$. After 1 month, the mineralized soil samples were collected and used for follow-up experiments. Control experiments were similarly carried out without bacteria.

\subsection{Sequential Extraction of $\mathrm{Cd}$}

The $\mathrm{Cd}$ in the $\mathrm{Cd}$-contaminated soil was measured by the Tessier sequential extraction procedure for 5 different fractions: exchangeable, carbonate-bound, Fe-Mn oxides-bound, organic matter-bound, and residual forms [29]. The extracts of 5 different fractions at a constant volume were measured using an atomic absorption spectrometer (novAA300, Analytik Jena AG, Jena, Germany).

\section{Results and Discussion}

\subsection{Screening and Identification of Bacteria}

The urea agar plates were used to choose positive strains authenticated by pink color resulting from the hydrolysis of urea products. After repeated screening, four strains of Cd-resistant and urease-producing strains were finally isolated, and the MIC value of the bacteria was $350 \mathrm{mg} / \mathrm{L}$; these strains were coded as CZW-2, CZW-5, CZW-9 and CZW-12.

The sequencing results of the strains were uploaded to the Biotechnology Information Bank and compared with the known sequences in GenBank [6]. The phylogenetic tree (Figure 1) reveals that strain CZW-2 corresponds to Cupriavidus sp. with 98\% certainty; CZW-5, CZW-9 and CZW-12 correspond to Bacillus sp. with $100 \%$ certainty. These strains were with strong heavy metal resistance and the capacity for biodegradation, and widely used to remove heavy metals from contaminated environments $[17,30]$. The genus Cupriavidus is a $\beta$-proteobacterium that thrives in some of the harshest environments [31]. In previous studies, Mergeay et al. [32] had isolated Cupriavidus metallidurans CH34 from industrial sites polluted by industrial wastes rich in toxic heavy metals, and found that it has strong heavy metal tolerance. Zhu et al. [8] isolated Bacillus cereus NS4 from the industrial soil of a battery factory, and utilized it on a large scale to remedy nickel contaminated soil. 


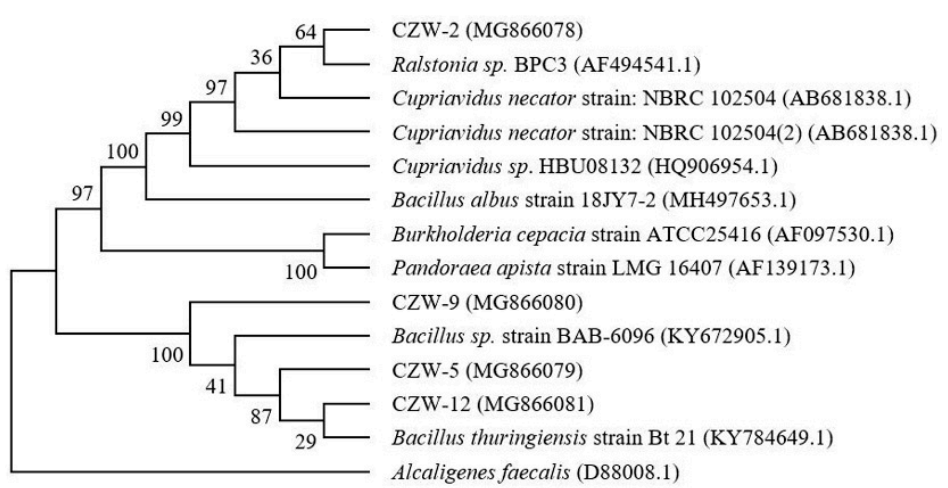

Figure 1. Neighbor-joining tree based on bacterial (CZW-2, CZW-5, CZW-9, CZW-12) 16S rDNA gene sequence data from different isolates obtained in the heavy metal-contaminated soil. Numerical values indicate bootstrap percentile from 1000 replicates. The 16S rDNA sequences of Alcaligens faecalis, Burkholderia cepacia and Pandoraea apista were included as outgroups.

\subsection{Enzyme Activities}

Urease is the key to the formation of precipitates of calcium carbonate in a medium containing the substrate urea and a calcium source [33]. The urease activity of four strains is shown in Figure 2. Among the isolated strains, $\mathrm{CZW}-2$ showed the highest urease activity was $51.6 \mathrm{U} / \mathrm{mL}$. The urease activities of CZW-5, CZW-9 and CZW-12 were $23.9 \mathrm{U} / \mathrm{mL}, 31.4 \mathrm{U} / \mathrm{mL}$ and $39.7 \mathrm{U} / \mathrm{mL}$, respectively. The above results were analyzed by the one-way ANOVA method in SPSS 22.0 (IBM, New York, NY, USA), and there were significant differences among all the data $(p<0.05)$. During the bacterial growth period, the urease activities of CZW-2 were obviously an advantage compared to the other three strains.

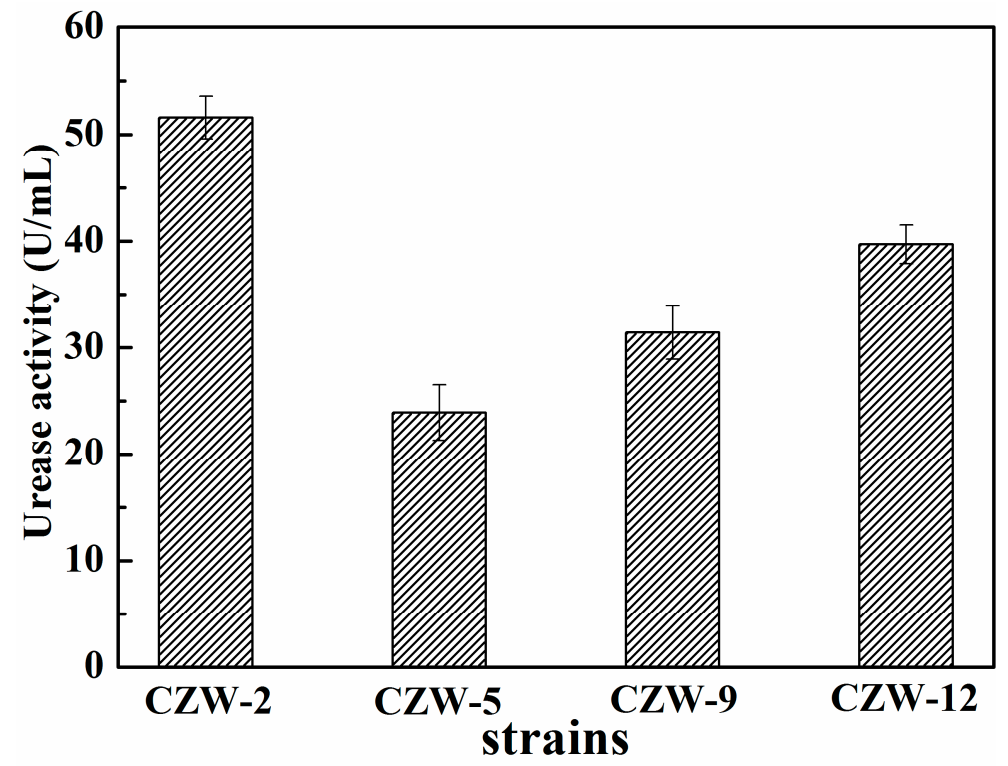

Figure 2. Urease activity of four isolated strains.

\subsection{Cd Precipitation Experiments}

Previous studies have shown that strains have higher urease activity under neutral or alkaline conditions $[34,35]$. In this study, the strains were added to a medium containing urea and $\mathrm{Cd}^{2+}$ at conditions of $\mathrm{pH}=7$ and $37^{\circ} \mathrm{C}$ for $\mathrm{Cd}^{2+}$ precipitation (Figure 3). Figure 3a shows the change in $\mathrm{pH}$ during the process of $\mathrm{Cd}$ precipitation for four strains. Compared with the other three bacteria, CZW-2 has a rapid increase in $\mathrm{pH}$ and a short delay time for the strain to enter the logarithmic growth stage. At this time, the bacteria multiply in the culture medium and produce urease to hydrolyze urea, 
thereby rapidly generating $\mathrm{NH}_{4}{ }^{+}$and $\mathrm{CO}_{3}{ }^{2-}$ to cause the $\mathrm{pH}$ increase, accelerating the biochemical reaction in the liquid environment [36]. The other three strains of CZW-5, CZW-9 and CZW-12 exhibit similar urease activity, $\mathrm{pH}$ value and removal rate. During $0-48 \mathrm{~h}$, the $\mathrm{pH}$ of the mineralization system exhibits a small increase. However, during $48-108 \mathrm{~h}$, the $\mathrm{pH}$ of the mineralization system increases by approximately 1.6, reaching values of 9.15, 9.17 and 9.11, respectively. After $108 \mathrm{~h}$, the four strains basically reach a stable phase at the same time. In short, strain CWZ-2 had the highest efficient hydrolysis of urea, and significantly better than the other three strains.

The removal rates of the four strains on the $\mathrm{Cd}$ precipitation experiments are different (Figure $3 \mathrm{~b}$ ). The initial total Cd concentration is approximately $2 \mathrm{mM}$. Within $120 \mathrm{~h}$, strain CZW-2 has a Cd ${ }^{2+}$ removal rate of $80.10 \%$. The other three strains of CZW-5, CZW-9 and CZW-12 exhibit close efficiency in the removal rate. The removal rates continuously increased within $0-84 \mathrm{~h}$ and reached the highest rates of $72.64 \%, 76.70 \%$ and $73.40 \%$ at $84 \mathrm{~h}$, respectively. Compared with the other three strains, strain CWZ-2 had the highest removal rate. The $\mathrm{pH}$ of the system increased but the removal rate remained stable from $84 \mathrm{~h}$ to $96 \mathrm{~h}$ (Figure 3b),. The reason for this is perhaps that when the number of bacteria or functional groups and other binding sites on the bacterial cell wall have all been occupied by metal ions, the existing urease in solutions still hydrolyzes the urea [37]. There can be many similar mechanisms for urease-producing bacteria to mineralize heavy metals. Choi et al. [38] screened Ralstonia sp. and Bacillus sp. strains from soil contaminated with heavy metals and diesel oil to remediate the metal contamination of $\mathrm{Cd}, \mathrm{Cu}$ and $\mathrm{Pb}$ with a removal efficiency of more than $90 \%$. Bacteria belonging to Bacillus are able to hydrolyze urea into $\mathrm{NH}_{4}{ }^{+}$and $\mathrm{CO}_{3}{ }^{2-}$ to precipitate calcite in their microenvironment $[39,40]$. Cheng et al. [41] determined that the free $\mathrm{Cd}^{2+}$ in soil can combine with the $\mathrm{CO}_{3}{ }^{2-}$ formed by the hydrolyzed urea by the strain to form crystals.

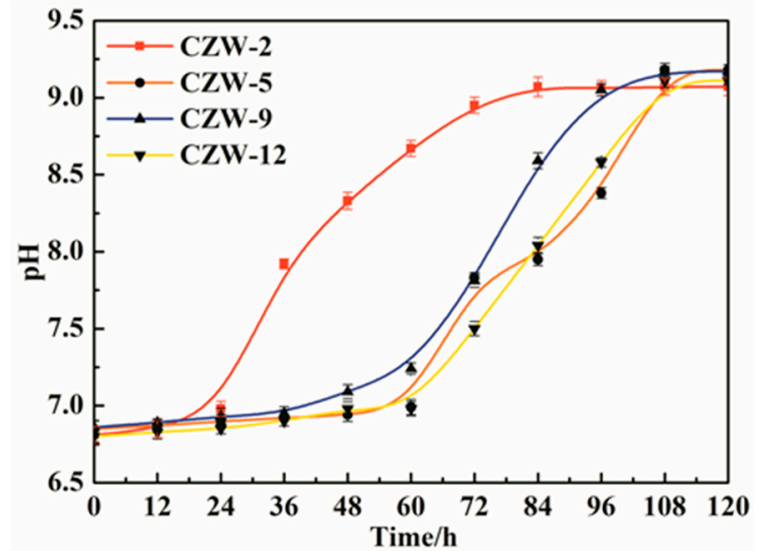

(a)

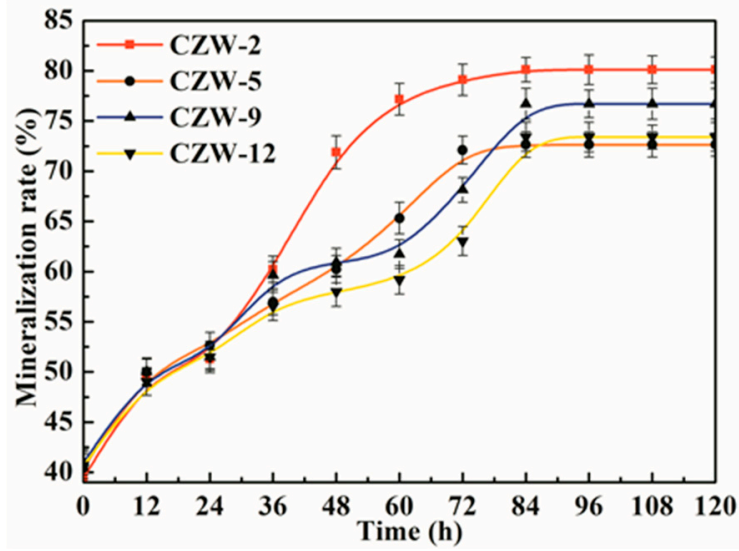

(b)

Figure 3. Analysis of the $\mathrm{pH}$ evolution (a) and removal rate (b) in the Cd precipitation experiments in $\mathrm{Cd}^{2+}$-LB broth from 0 to $120 \mathrm{~h}$.

\subsection{XRD Analysis}

To qualitatively analyze the precipitated substances, XRD analysis was carried out. The XRD spectra of the precipitated substances produced by CZW-2, CZW-5, CZW-9 and CZW-12 mineralization were observed (Figure 4). The XRD spectra revealed that the mineralized products were $\mathrm{CdCO}_{3}$. The peak intensity decreased in the following order: CZW-2 > CZW-12 > CZW-9 > CZW- 5 . The main $\mathrm{CdCO}_{3}$ peak of $\mathrm{CZW}-2$ was much higher than the other three strains, and showed that the degree of crystallinity of CZW-2 was better than that of the other three. This relationship indicates that the higher the peak, the smaller the peak width, and the better the crystallinity [42]. 


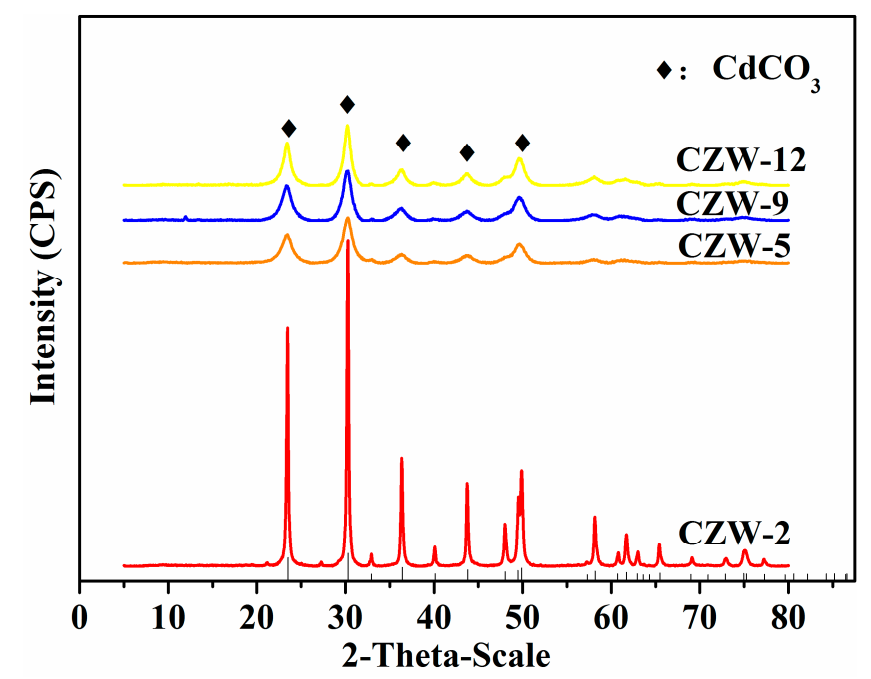

Figure 4. XRD analysis of the precipitates produced by CZW-2, CZW-5, CZW-9 and CZW-12. Identified peaks: $\mathrm{CdCO}_{3}(\diamond)$.

\subsection{SEM and EDS Analyses}

Bacterial activity controls the mineralization process to control mineral nucleation growth $[43,44]$, and the types of the precipitated mineral that are affected by the microbial species [45]. The precipitations mineralized by strains CZW-2, CZW-5, CZW-9 and CZW-12 were analyzed by scanning electron microscopy and energy dispersive X-ray spectroscopy (SEM-EDS) (Figure 5). The mineral precipitated by strain CZW-2 was an oval-shaped mineralized product, and its diameter was approximately $0.5 \mu \mathrm{m}$. The SEM images showed that the number of crystals was many and that all of the fine particles clustered together (Figure 5a). Combined with Figures 2 and 3, a large quantity of precipitation occurred because of the high urease activity of the strain, which rapidly hydrolyzed the urea to produce much $\mathrm{CO}_{3}{ }^{2-}$; thus, $\mathrm{Cd}^{2+}$ can be combined with $\mathrm{CO}_{3}{ }^{2-}$ to form a large number of small mineral crystal diameter precipitates in a short time, resulting in excessive $\mathrm{Cd}^{2+}$ binding sites by the bacterial cell. The precipitation mineralized by strain CZW- 5 was a spherical shape with a diameter of approximately $2 \mu \mathrm{m}$, and a small rod-shaped precipitate was attached to the precipitated large particles (Figure 5b). Bacteria play an important role in the biomineralization of $\mathrm{CdCO}_{3}$ because they provide a large number of nucleation sites and hydrolyze the substrate to control the specific morphology of crystals [46]. The precipitation mineralized by strain CZW-9 was also spherical; the largest diameter is approximately $1 \mu \mathrm{m}$, and most are smaller than $1 \mu \mathrm{m}$ (Figure $5 \mathrm{c}$ ). However, this strain produced significantly fewer crystal nucleation sites than strain CZW-2. In comparison, in the mineralized precipitation of CZW-5, the small-diameter crystals are mostly clustered together to form a large number of small spherical bodies. The mineral precipitate mineralized by strain CZW-12 was similar to those of strains CZW-2 and CZW-9. The crystal volume of the precipitate is small, most of the crystal diameters are less than $1 \mu \mathrm{m}$ and the precipitates are clustered and piled up (Figure $5 \mathrm{~d}$ ).

The SEM images of the mineralized product induced by different strains revealed that the diameter of $\mathrm{CdCO}_{3}$ ranked from 0.5 to $2 \mu \mathrm{m}$. Interactions between bacteria and minerals indicate that minerals provide a place for bacterial activity, and bacteria can promote or inhibit the growth of minerals, resulting in significant differences in morphology, diameter and bulk density of the precipitates [47]. The differences in bacterial strains and urease activity can also lead to differences in the shapes of precipitates [48,49]. Paassen [12] found that the types of calcium carbonate crystals produced by MICP (Microbially Induced Calcite Precipitation) are mainly related to the hydrolysis rate of urea. In addition, the increase of the number of bacteria would increase the precipitation rate of calcium carbonate, because the bacterial cell was the nucleation site of the new crystal precipitation. When more bacteria were present, due to the abundant nucleation sites, $\mathrm{CO}_{3}{ }^{2-}$ was consumed by the formation of new crystal precipitation, rather than promoting the growth of the existing crystal, which happened in 
the case of a small number of bacterial cells [50]. This phenomenon has been well studied in the production of calcium carbonate by the pure chemical method, where a large number of nucleation sites leads to greater formation of small crystals, and vice versa [51].
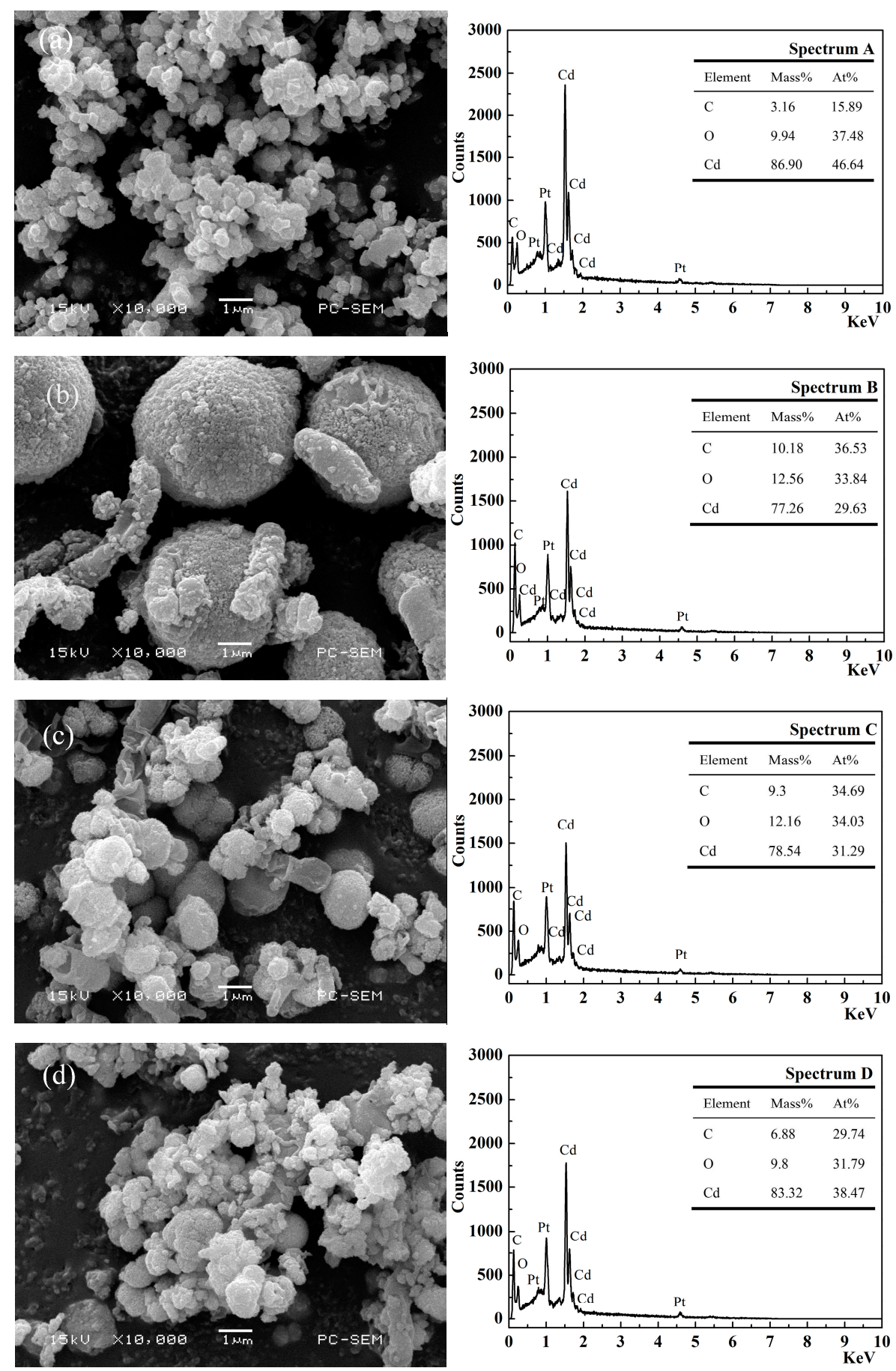

Figure 5. Scanning electron microscopy and energy dispersive $X$-ray spectroscopy (SEM-EDS) analysis of the precipitates produced by CZW-2, CZW-5, CZW-9 and CZW-12. (a): CZW-2, (b): CZW-5, (c): CZW-9, (d): CZW-12. Elemental composition displayed in the graphs indicates that they are composed of $\mathrm{Cd}, \mathrm{C}$ and $\mathrm{O}$.

To identify the elements in the minerals, the minerals were analyzed by EDS (Figure 5, Spectrum $\mathrm{A}, \mathrm{B}, \mathrm{C}, \mathrm{D})$. The mass percentages of $\mathrm{Cd}$ in the precipitations mineralized by strains $\mathrm{CZW}-2$, CZW-5, CZW-9 and CZW-12 were 86.90\%, 77.26\%, 78.54\% and 83.32\%, respectively. The mineral 
precipitates containing heavy metal of CZW-2 and CZW-12 had higher ratios of Cd. Combined with Figures 4-6, the absorption frequency of $\mathrm{CdCO}_{3}$ and $\mathrm{CO}_{3}{ }^{2-}$ were $\mathrm{CZW}-2>\mathrm{CZW}-12>\mathrm{CZW}-9>\mathrm{CZW}-5$. These results imply that the mineral crystallinity exhibits a positive correlation with the absorption frequency and is also consistent with the elemental composition of the EDS energy spectrum, but has a negative correlation with the crystal diameter.

\subsection{FTIR Spectroscopy}

Through Fourier transform infrared spectroscopy analysis, the main functional groups can be determined by obtaining the characteristic peak of microbial mineralization. The peak value of the infrared spectrum of $\mathrm{CdCO}_{3}$ precipitation is mainly determined by the internal vibration of $\mathrm{CO}_{3}{ }^{2-}$, the absorption frequency of $\mathrm{CO}_{3}{ }^{2-}$ in the infrared region, the strong absorption peak of $1530-1320 \mathrm{~cm}^{-1}$, and the weak absorption peaks of $1100-1040 \mathrm{~cm}^{-1}, 890-800 \mathrm{~cm}^{-1}$ and $745-670 \mathrm{~cm}^{-1}$. The absorption peak located at $3400 \mathrm{~cm}^{-1}$ is the stretching vibration peak of $\mathrm{O}-\mathrm{H}$ and N-H bonds, and the absorption peak of crystal water around $1643 \mathrm{~cm}^{-1}$. As shown in Figure 6, the strong absorption peaks in the $1530-1320 \mathrm{~cm}^{-1}$ region and the weak peaks in the ranges of $1100-1040 \mathrm{~cm}^{-1}$ and $890-800 \mathrm{~cm}^{-1}$ are all the $\mathrm{C}-\mathrm{O}$ bonding of $\mathrm{CdCO}_{3}$ crystals [52]. The out-of-plane bending vibration peak occurs at $710.01 \mathrm{~cm}^{-1}$, the in-plane bending vibration peak occurs at $862 \mathrm{~cm}^{-1}$, and the symmetrical and asymmetrical stretching vibrational peaks occur at $1060 \mathrm{~cm}^{-1}$ and $1420.41 \mathrm{~cm}^{-1}$, respectively $[53,54]$. The strong absorption peak that appeared at $1410.2 \mathrm{~cm}^{-1}$ was the absorption peak of $\mathrm{CO}_{3}{ }^{2-}$. The infrared absorption peak intensities of the mineral samples of the four strains decreased from CZW-2 > CZW-12 > CZW-9 > CZW-5, and the mineral crystallinity decreased from CZW-2 $>$ CZW-12 > CZW-9 > CZW-5. Also, the mineral crystallinity exhibits a positive correlation with the crystal peak size of the precipitation in Figure 4 and a negative correlation with the mineral grain size in Figure 5. Compared with the infrared spectra of the CZW-5 mineral precipitation, which exhibited peaks at 847 and $1411 \mathrm{~cm}^{-1}$, the strong absorption peaks of the other three precipitates are as follows: CZW-2: $855 \mathrm{~cm}^{-1}, 1411 \mathrm{~cm}^{-1}$; CZW-9: $855 \mathrm{~cm}^{-1}, 1434 \mathrm{~cm}^{-1}$; CZW-12: $855 \mathrm{~cm}^{-1}$, $1434 \mathrm{~cm}^{-1}$. These strong absorption peaks exhibited blueshift, which indicates that the carbonate group is more stable. The functional groups on the surfaces of microorganisms act as binding sites for many chemicals, especially trace metals, and also adhere to the surfaces of cells and minerals [55]. Microorganisms can secrete one or more metabolites and combine with chemicals in the system to produce minerals [56].

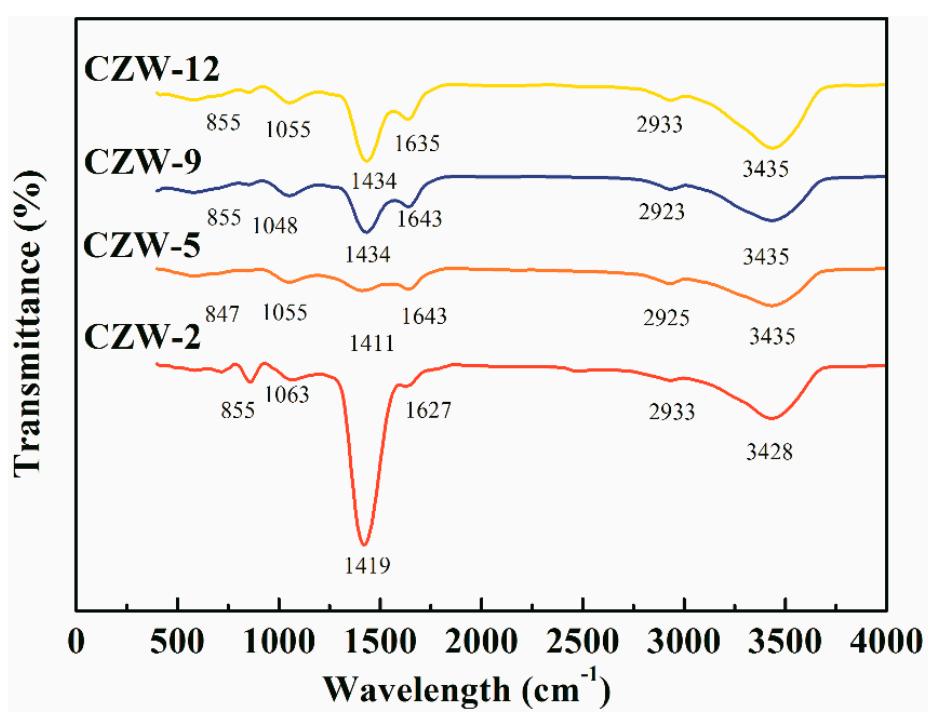

Figure 6. Fourier transform infrared spectroscopy (FTIR) analysis of the precipitates produced by CZW-2, CZW-5, CZW-9 and CZW-12. 


\subsection{Cd Analysis after Bioremediation}

The bioremediation efficiency of isolated strains was tested in Cd-contaminated soil. Soil samples had an initial total Cd concentration of $5.10 \mathrm{mg} / \mathrm{kg}$. The results of the bioremediation of strains and control after one month are shown in Figure 7. The five fractions in the control soil samples showed the following distribution: exchangeable $>$ carbonate-bound $>$ Fe-Mn oxides-bound $>$ organic matter-bound $>$ residual forms. In the remediated soil samples, the following distribution was obtained: carbonate-bound $>$ Fe-Mn oxides-bound $>$ exchangeable $>$ organic matter-bound $>$ residual forms. Compared to the control samples, the carbonate-bound and exchangeable fractions in the bioremediation soils changed significantly; the carbonate-bound fractions in the bioremediation soils by the mineralization of the strains CZW-2, CZW-5, CZW-9 and CZW- 12 increased by $55.42 \%$, $20.27 \%, 39.67 \%$ and $34.36 \%$, while the exchangeable fraction decreased by $53.30 \%, 35.33 \%, 42.54 \%$ and $53.80 \%$, respectively. However, there was no obvious change in Fe-Mn oxide fraction of Cd in the bioremediation soils and the control. The limited interaction between the isolated four strains and Fe-Mn oxide fractions of $\mathrm{Cd}$ may be due to the limited bioavailability [22]. The organic matter bound part of $\mathrm{Cd}$ may be complexed or adsorbed as was reported by previous studies [6]. Therefore, the interactions between bacteria and metals are inhibited. The residual fraction of $\mathrm{Cd}$ did not change significantly in the bioremediation soils and the control, which, due to the residual fraction of $\mathrm{Cd}$, are tightly bound and very stable under natural conditions [57].

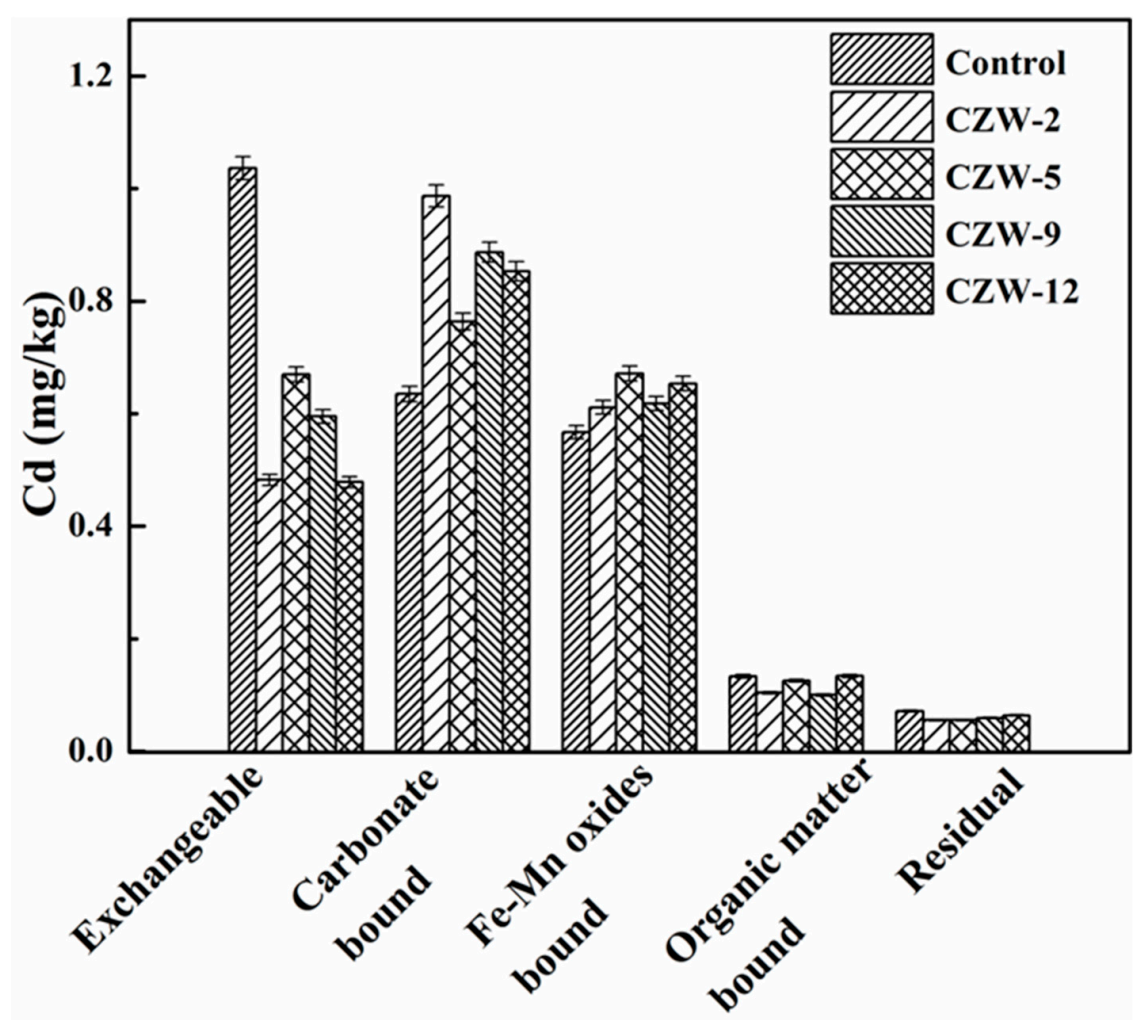

Figure 7. The distribution of $\mathrm{Cd}$ in different fractions of the control and bioremediated Cdcontaminated soil.

It is thus clear that all four strains can reduce the bioavailability of $\mathrm{Cd}$ through immobilizing the $\mathrm{Cd}$ from Cd-contaminated soil, but with different degrees of variation in the exchangeable fraction and the carbonate-bound fraction. CZW-2 was more effective in bioremediation soils compared with other three groups, due to the increase in the bacteria cell growth, and the urease activity showed a difference, which coincided with the research by Zhu et al. and Li et al. [8,11]. Zeng et al. [58] found Cupriavidus sp. ZSK had high tolerance to heavy metals, such as $\mathrm{Cd}, \mathrm{Cu}, \mathrm{Zn}, \mathrm{Cr}(\mathrm{VI})$ and $\mathrm{Pb}$ ions, 
and suggested that Cupriavidus sp. ZSK was a potential microorganism to adsorb $\mathrm{Cd}$ and other metals from waste water. The remediation by bacterial treatment can alleviate the exchangeable fractions of heavy metals. Thus, the mobility and bioavailability of highly toxic heavy metals can be effectively controlled. Further, the data obtained in this study have provided an effective theoretical basis for soil remediation in large areas.

\section{Conclusions}

In summary, four urease-producing strains (CZW-2, CZW-5, CZW-9, CZW-12) isolated in the abandoned mine were all capable of tolerating high concentrations of $\mathrm{Cd}$ and effectively converted soluble $\mathrm{Cd}$ into insoluble carbonate minerals. Further, the mineral precipitates from different strains had varied mineral morphologies, diameters and crystallinities, which were significantly correlated with bacterial urease activity. Biomineralization of Cd-contaminated soils with bacteria significantly revealed that the four strains can effectively reduce the exchangeable fraction of $\mathrm{Cd}$ but increased the carbonate-bound fraction. Therefore, these four stains can alleviate the mobility and bioavailability of $\mathrm{Cd}$ in Cd-contaminated soils. However, this study only describes the results of bioremediation of Cd-contaminated soil obtained during a period of 30 days. In future research, we will focus on the changes in soil properties and morphology after remediation by bacterial treatment. Introduction of this indigenous bacterium provides a potential in situ bioremediation technology without disturbing the target environment, which also provides a new theoretical reference for removing heavy metals in wastewater and soils.

Author Contributions: X.Z. and M.W. participated in various stages of the experiment, including the concept of the experimental framework and the paper writing. H.W. and D.T. conducted experimental soils collection. J.H. and Y.S. made suggestions for the writing of the thesis. All the authors have read and approved the manuscript.

Funding: This research was supported by the National Natural Youth Science Foundation of China (No. 41302025) and the National Natural Science Foundation of China (No. 41541016).

Conflicts of Interest: The authors declare no conflict of interest.

\section{References}

1. Liu, Y.; Yang, Y.; Li, C.; Ni, X.; Ma, W.; Wei, H. Assessing Soil Metal Levels in an Industrial Environment of Northwestern China and the Phytoremediation Potential of Its Native Plants. Sustainability 2018, 10, 2686. [CrossRef]

2. Kwapulinski, J.; Paukszto, A.; Paprotny, Ł.; Musielinska, R.; Kowol, J.; Nogaj, E.; Rochel, R. Bioavailability of Lead, Cadmium, and Nickel in Tatra Mountain National Park Soil. Pol. J. Environ. Stud. 2012, 21, 407-413.

3. Jean, L.; Bordas, F.; Bollinger, J.C. Chromium and nickel mobilization from a contaminated soil using chelants. Environ. Pollut. 2007, 147, 729-736. [CrossRef] [PubMed]

4. Basta, N.; Gradwohl, R. Estimation of $\mathrm{Cd}, \mathrm{Pb}$, and $\mathrm{Zn}$ bioavailability in smelter-contaminated soils by a sequential extraction procedure. J. Soil. Contam. 2000, 9, 149-164. [CrossRef]

5. Qin, L.; Xie, D.; Zhu, W.; Shi, M.; Xiong, Q. The characteristics of riparian heavy metal pollution in Tumen River. J. Arid Land Resour. Environ. 2015, 29, 120-125.

6. Achal, V.; Pan, X.; Fu, Q.; Zhang, D. Biomineralization based remediation of As(III) contaminated soil by Sporosarcina ginsengisoli. J. Hazard. Mater. 2012, 201, 178-184. [CrossRef]

7. Ike, M.; Miyazaki, T.; Yamamoto, N.; Sei, K.; Soda, S. Removal of arsenic from groundwater by arsenite-oxidizing bacteria. Water Sci. Technol. J. Int. Assoc. Water Pollut. Res. 2008, 58, 1095-1100. [CrossRef] [PubMed]

8. Zhu, X.; Li, W.; Zhan, L.; Huang, M.; Zhang, Q.; Achal, V. The large-scale process of microbial carbonate precipitation for nickel remediation from an industrial soil. Environ. Pollut. 2016, 219, 149-155. [CrossRef] [PubMed]

9. Ali, M.M.; Ali, M.L.; Islam, M.S.; Rahman, M.Z. Preliminary assessment of heavy metals in water and sediment of Karnaphuli River, Bangladesh. Environ. Nanotechnol. Monit. Manag. 2016, 5, 27-35. [CrossRef] 
10. Zhao, Y.; Yao, J.; Yuan, Z.; Wang, T.; Zhang, Y.; Wang, F. Bioremediation of Cd by strain GZ-22 isolated from mine soil based on biosorption and microbially induced carbonate precipitation. Environ. Sci. Pollut. Res. 2017, 24, 372-380. [CrossRef]

11. Li, M.; Cheng, X.; Guo, H. Heavy metal removal by biomineralization of urease producing bacteria isolated from soil. Int. Biodeterior. Biodegrad. 2013, 76, 81-85. [CrossRef]

12. Paassen, L.A.V. Biogrout, Ground Improvement by Microbial Induced Carbonate Precipitation; TU: Delft, The Netherlands, 2009.

13. Kang, C.H.; So, J.S. Heavy metal and antibiotic resistance of ureolytic bacteria and their immobilization of heavy metals. Ecol. Eng. 2016, 97, 304-312. [CrossRef]

14. Arias, D.; Cisternas, L.A.; Rivas, M. Biomineralization of calcium and magnesium crystals from seawater by halotolerant bacteria isolated from Atacama Salar (Chile). Desalination 2017, 405, 1-9. [CrossRef]

15. Sangeeta, C.; Pinaki, S. Uranium biomineralization by a metal resistant Pseudomonas aeruginosa strain isolated from contaminated mine waste. J. Hazard. Mater. 2011, 186, 336-343.

16. Mitchell, A.C.; Ferris, F.G. The coprecipitation of Sr into calcite precipitates induced by bacterial ureolysis in artificial groundwater: Temperature and kinetic dependence. Geochim. Cosmochim. Acta 2005, 69, 4199-4210. [CrossRef]

17. Yamamura, S.; Ike, M.; Fujita, M. Dissimilatory arsenate reduction by a facultative anaerobe, Bacillus sp. strain SF-1. J. Biosci. Bioeng. 2003, 96, 454-460. [CrossRef]

18. Kang, C.H.; Kwon, Y.J.; So, J.S. Bioremediation of heavy metals by using bacterial mixtures. Ecol. Eng. 2016, 89, 64-69. [CrossRef]

19. Kang, C.H.; Han, S.H.; Soo Ji, O.H.; Shin, Y.J.; Kim, Y.; Jaeseong, S.O. Bioremediation of Cd by Microbially Induced Calcite Precipitation. Appl. Biochem. Biotechnol. 2014, 172, 1929-1937. [CrossRef]

20. Annu; Garg, A.; Urmila. Level of Cd in different types of soil of Rohtak district and its bioremediation. J. Environ. Chem. Eng. 2016, 4, 3797-3802. [CrossRef]

21. Kang, C.H.; Oh, S.J.; Shin, Y.J.; Han, S.H.; Nam, I.H.; So, J.S. Bioremediation of lead by ureolytic bacteria isolated from soil at abandoned metal mines in South Korea. Ecol. Eng. 2015, 74, 402-407. [CrossRef]

22. Muthusamy, G.; Kui-Jae, L.; Min, C.; Jae Su, K.; Seralathan, K.K.; Byung-Taek, O. Significance of autochthonous Bacillus sp. KK1 on biomineralization of lead in mine tailings. Chemosphere 2013, 90, 2267-2272.

23. Kannan, S.K.; Mahadevan, S.; Krishnamoorthy, R. Characterization of a mercury-reducing Bacillus cereus strain isolated from the Pulicat Lake sediments, south east coast of India. Arch. Microbiol. 2006, 185, $202-211$. [CrossRef] [PubMed]

24. Achal, V.; Pan, X. Characterization of urease and carbonic anhydrase producing bacteria and their role in calcite precipitation. Curr. Microbiol. 2011, 62, 894-902. [CrossRef] [PubMed]

25. Tang, Y.Q.; Ji, P.; Lai, G.; Chi, C.; Liu, Z.; Wu, X. Diverse microbial community from the coalbeds of the Ordos Basin, China. Int. J. Coal. Geol. 2012, 90, 21-33. [CrossRef]

26. Whiffin, V.S. Microbial $\mathrm{CaCO}_{3}$ Precipitation for the Production of Biocement. Ph.D. Thesis, Murdoch University, Murdoch, Australia, 2004.

27. Whiffin, V.S.; Paassen, L.A.V.; Harkes, M.P. Microbial Carbonate Precipitation as a Soil Improvement Technique. Geomicrobiol. J. 2007, 24, 417-423. [CrossRef]

28. Chao, Y.; Zhang, T. Optimization of fixation methods for observation of bacterial cell morphology and surface ultrastructures by atomic force microscopy. Appl. Microbiol. Biot. 2011, 92, 381-392. [CrossRef] [PubMed]

29. Tessier, A.; Campbell, P.G.C.; Bisson, M. Sequential extraction procedure for the speciation of particulate trace metals. Anal. Chem. 1979, 51, 844-851. [CrossRef]

30. Zhao, X.; Wang, R.; Lu, X.; Lu, J.; Li, J.; Hu, H. Tolerance and Biosorption of Heavy Metals by Cupriavidus metallidurans strain XXKD-1 Isolated from a Subsurface Laneway in the Qixiashan $\mathrm{Pb}-\mathrm{Zn}$ Sulfide Minery in Eastern China. Geomicrobiol. J. 2012, 29, 274-286. [CrossRef]

31. Diels, L.; Roy, S.V.; Taghavi, S.; Houdt, R.V. From industrial sites to environmental applications with Cupriavidus metallidurans. Anton. Leeuw. Int. J. Gen. 2009, 96, 247-258. [CrossRef]

32. Mergeay, M.; Houba, C.; Gerits, J. Extrachromosomal inheritance controlling resistance tocadmium, cobalt, copper and zinc ions: Evidence from curing a Pseudomonas. Arch. Int. Physiol. Biochim. 1978, 86, 440-442. 
33. Muynck, W.D.; Belie, N.D.; Verstraete, W. Microbial carbonate precipitation in construction materials: A review. Ecol. Eng. 2010, 36, 118-136. [CrossRef]

34. Anne, S.; Rozenbaum, O.; Andreazza, P.; Rouet, J.L. Evidence of a bacterial carbonate coating on plaster samples subjected to the Calcite Bioconcept biomineralization technique. Constr. Build. Mater. 2010, 24, 1036-1042. [CrossRef]

35. Prah, J.; Maček, J.; Dražič, G. Precipitation of calcium carbonate from a calcium acetate and ammonium carbamate batch system. J. Cryst. Growth 2011, 324, 229-234. [CrossRef]

36. Walker, W.J.; Mcnutt, R.P.; Maslanka, C.K. The potential contribution of urban runoff to surface sediments of the Passaic River: Sources and chemical characteristics. Chemosphere 1999, 38, 363-377. [CrossRef]

37. Wu, Q.; Liu, G.; Zheng, X.; Ren, J. Screening of Heavy Metal Tolerant Microbes in Sludge and Removal Capability of Lead. J. Residuals Sci. Technol. 2015, 12, 85-91. [CrossRef]

38. Aejung, C.; Wang, S.K.; Minhee, L. Biosorption of cadmium, copper, and lead ions from aqueous solutions by Ralstonia sp. and Bacillus sp. isolated from diesel and heavy metal contaminated soil. Geosci. J. 2009, 13, 331-341.

39. Castanier, S.; Métayer-Levrel, G.L.; Perthuisot, J.P. Ca-carbonates precipitation and limestone genesisThe microbiogeologist point of view. Sediment. Geol. 1999, 126, 9-23. [CrossRef]

40. Hammes, F.; Seka, A.; De, K.S.; Verstraete, W. A novel approach to calcium removal from calcium-rich industrial wastewater. Water Res. 2003, 37, 699-704. [CrossRef]

41. Cheng, L.; Qian, C.; Wang, R.; Wang, J. Bioremediation process of $\mathrm{Cd}^{2+}$ removal from soil by bacteria a biomineralization. J. Chin. Ceram. Soc. 2008, 36, 215-221.

42. Chen, Z.; Pan, X.; Chen, H.; Guan, X.; Lin, Z. Biomineralization of Pb(II) into Pb-hydroxyapatite induced by Bacillus cereus 12-2 isolated from Lead-Zinc mine tailings. J. Hazard. Mater. 2015, 301, 531-537. [CrossRef]

43. Benzerara, K.; Miot, J.; Morin, G.; Ona-Nguema, G.; Skouri-Panet, F.; Férard, C. Significance, mechanisms and environmental implications of microbial biomineralization. CR Géosci. 2011, 343, 160-167. [CrossRef]

44. Phillips, A.J.; Gerlach, R.; Lauchnor, E.; Mitchell, A.C.; Cunningham, A.B.; Spangler, L. Engineered applications of ureolytic biomineralization: A review. Biofouling 2013, 29, 715-733. [CrossRef] [PubMed]

45. Frankel, R.B. Biologically Induced Mineralization by Bacteria. Rev. Miner. Geochem. 2013, 54, 95-114. [CrossRef]

46. Rodriguez-Navarro, C.; Jroundi, F.; Schiro, M.; Ruiz-Agudo, E.; González-Muñoz, M.T. Influence of substrate mineralogy on bacterial mineralization of calcium carbonate: Implications for stone conservation. Appl. Environ. Microbiol. 2012, 78, 4017-4029. [CrossRef] [PubMed]

47. Teng, H.; Hu, Q.; Lian, B.; Ji, J.; Chen, J. Carbonate biomineralization induced by soil bacterium Bacillus megaterium. Geochim. Cosmochim. Acta 2006, 70, 5522-5535. [CrossRef]

48. Hammes, F.; Boon, N.; De, V.J.; Verstraete, W.; Siciliano, S.D. Strain-specific ureolytic microbial calcium carbonate precipitation. Appl. Environ. Microbiol. 2003, 69, 4901-4909. [CrossRef] [PubMed]

49. Park, S.J.; Park, Y.M.; Chun, W.Y.; Kim, W.J.; Ghim, S.Y. Calcite-forming bacteria for compressive strength improvement in mortar. J. Microbiol. Biotechnol. 2010, 20, 782-788. [PubMed]

50. Dejong, J.T.; Mortensen, B.M.; Martinez, B.C.; Nelson, D.C.; Jonkers, H.M.; Loosdrecht, M.C.M.V. Bio-mediated soil improvement. Ecol. Eng. 2010, 36, 197-210. [CrossRef]

51. Al-Thawadi, S.M. Consolidation of Sand Particles by Aggregates of Calcite Nanoparticles Synthesized by Ureolytic Bacteria under non-Sterile Conditions. J. Chem. Sci. Technol. 2013, 2, 141-146.

52. Beech, I.; Hanjagsit, L.; Kalaji, M.; Neal, A.L.; Zinkevich, V. Chemical and structural characterization of exopolymers produced by Pseudomonas sp. NCIMB 2021 in continuous culture. Microbiology 1999, 145, 1491-1497. [CrossRef]

53. Fein, J.B.; Martin, A.M.; Wightman, P.G. Metal adsorption onto bacterial surfaces: Development of a predictive approach. Geochim. Cosmochim. Acta 2001, 65, 4267-4273. [CrossRef]

54. Yang, S.L.; Wei, S. Study on Precipitation Process of Spherical Calcium Carbonate Controlled by Polyaspartic Acid. J. Synth. Cryst. 2013, 42, 1475-1480.

55. Burns, J.L.; Ginn, B.R.; Bates, D.J.; Dublin, S.N.; Taylor, J.V.; Apkarian, R.P.; Amaro-Garcia, S.; Neal, A.L.; Dichristina, T.J. Outer membrane-associated serine protease involved in adhesion of Shewanella oneidensis to Fe(III) oxides. Environ. Sci. Technol. 2010, 44, 68-73. [CrossRef] [PubMed] 
56. Huang, J.H.; Elzinga, E.J.; Brechbuehl, Y.; Voegelin, A.; Kretzschmar, R. Impacts of Shewanella putrefaciens strain CN-32 cells and extracellular polymeric substances on the sorption of As(V) and As(III) on Fe(III)-(hydr)oxides. Environ. Sci. Technol. 2011, 45, 2804-2810. [CrossRef] [PubMed]

57. Xian, X. Effect of chemical forms of cadmium, zinc, and lead in polluted soils on their uptake by cabbage plants. Plant Soil 1989, 113, 257-264. [CrossRef]

58. Zeng, X.; Wu, L.; Li, W.; Zhu, S.; Wei, B.; Tang, J.; Tan, Y. Characterization of Strain Cupriavidus sp. ZSK and Its Biosorption of Heavy Metal Ions. J. Biobased Mater. Bioenergy 2017, 11, 154-158. [CrossRef]

(C) 2019 by the authors. Licensee MDPI, Basel, Switzerland. This article is an open access article distributed under the terms and conditions of the Creative Commons Attribution (CC BY) license (http:/ / creativecommons.org/licenses/by/4.0/). 